\title{
Kniest Dysplasia
}

National Cancer Institute

\section{Source}

National Cancer Institute. Kniest Dysplasia. NCI Thesaurus. Code C125594.

A rare, autosomal dominant inherited bone growth disorder caused by mutations in the COL2A1gene. It is characterized by short stature (dwarfism) and other skeletal abnormalities, round, flat face with bulging and wide-set eyes, myopia and retinal detachment that can lead to blindness. 